\title{
Growth of multipurpose tree species (MPTS) as influenced by various soil moisture conservation techniques under rainfed conditions
}

\author{
S.M. TALEY, S.C. VILHEKAR AND K.A. JADHAO
}

Article Chronicle :

Received:

30.05.2014;

Revised:

01.04.2015;

Accepted :

22.04.2015

Key Words :

Growth, Biomass,

Moisture

conservation

techniques
ABSTRACT : The present experiment was conducted on medium deep silty loam soil to study the effect of rain water conservation techniques on growth of multipurpose tree species (MPTS) in terms of height and collar diameter. The experiment was conducted during the year 2012-2014 on AEEC Farm, Dr. Panjabrao Deshmukh Agriculture University, Akola with five treatments viz., half-moon terracing $\left(\mathrm{T}_{1}\right)$, mulching with locally available grasses @ $10 \mathrm{~kg} / \mathrm{plant}\left(\mathrm{T}_{2}\right)$, compartment bunding with bund height of $0.15 \mathrm{~m}\left(\mathrm{~T}_{3}\right)$, use of soybean as cover crop $\left(\mathrm{T}_{4}\right)$ and control $\left(\mathrm{T}_{5}\right)$ and four replications in Randomized Block Design. The results revealed that plant height and collar diameter of tree species were found significantly highest in half moon terracing $\left(\mathrm{T}_{1}\right)$ followed by mulching with locally available grasses @ $10 \mathrm{~kg} / \mathrm{plant}\left(\mathrm{T}_{2}\right)$ as compared to other treatments. Soil moisture content of Karanj, Sitaphal and Bel at different soil depths was also found highest in half-moon terracing $\left(\mathrm{T}_{1}\right)$ and mulching with locally available grasses @ $10 \mathrm{~kg} /$ plant $\left(\mathrm{T}_{2}\right)$.

How to CITE THIS ARTICLE : Taley, S.M., Vilhekar, S.C. and Jadhao, K.A. (2015). Growth of multipurpose tree species (MPTS) as influenced by various soil moisture conservation techniques under rainfed conditions. Asian J. Environ. Sci., 10(1): 29-33. 